УДК 340.12:396.2:347.962.1

DOI https://doi.org/10.32837/apdp.v0i83.113

Ю. Ю. Боброва

\title{
ОГЛЯД РЕЗУЛЬТАТІВ ДОСЛІДЖЕННЯ ГЕНДЕРНОГО АСПЕКТУ судДІВСЬКОЇ ДІЯЛЬНОСТІ
}

Постановка проблеми. На сьогодні не прослідковується взаємозалежність понять «Гендерна рівність» $\mathrm{i}$ «судова гілка влади», а ґендерний аспект у суддівській діяльності є новим правовим явищем. Хоч він і набув актуальності для суддівської спільноти, однак ще не піднімався на загал, а тому потребує всебічного грунтовного наукового аналізу.

Аналіз останніх досліджень і публікацій. Поряд із розмаїтістю та значною кількістю опублікованих праць із ґендерної проблематики спостерігається відсутність комплексного правового бачення цього феномену, не вистачає фундаментальних робіт, у яких був би представлений цілісний аналіз суддівської діяльності, а загальнотеоретичні питання ґендерної рівності суддів ще не були предметом наукового інтересу вітчизняних науковців.

Правовим аспектам гендерної рівності в Україні присвячені праці вітчизняних та зарубіжних вчених-ґендеристів: С. Айвазової, Н. Аніщук, Н. Болотіної, М. Буроменського, О. Вороніної, В. Глиняного, О. Дашковської, Л. Завадської, Л. Кормич, Н. Лавріненко, І. Лаврінчук, К. Левченко, Л. Леонтьєвої, Т. Марценюк, О. Матвієнко, Т. Мельник, Н. Оніщенко, Л. Петришиної, Н. Пушкарьової, С Поленіної, О. Руднєвої, 3. Ромовської, Л. Смоляр, Г. Терещенка, М. Томашевської та інших.

Метою статті є огляд результатів дослідження гендерного аспекту суддівської діяльності.

Виклад основного матеріалу дослідження. Автором було проведено емпіричне дослідження ряду ґендерних аспектів суддівської діяльності, у процесі якого використані опитування та застосований статистичний аналіз для обробки та узагальнення його результатів. Вибірка є репрезентативною штатному складу судів 3 урахуванням розподілу за інстанційністю та регіонами. У дослідженні, яке проводилося у лютому-червні 2019 року, взяли участь 200 суддів першої та апеляційної інстанцій Івано-Франківської, Київської, Луганської, Тернопільської, Чернівецької областей України та м. Києва. Соціально-демографічні характеристики досліджуваних: стать: 94 жінок, 106 - чоловіків. Вік досліджуваних - від 30 до 60 років.

Автор з'ясовала, що гендерна проблематика має глибоке історичне коріння. Немає сумніву, що починаючи з античних часів і середньовічного феодалізму жінки не мали рівного із чоловіками правового статусу. На жаль, і нині він носить дуже часто декларативний характер. В Україні ґендерні дослідження почали набувати актуальності після здобуття нею незалежності та проголошення курсу демократії, а з нею і ґендерної рівності у тому числі і в суддівській діяльності. Як свідчать дані проведеного автором емпіричного дослідження, з тим, що для судової системи України надане законодавцем право жінці бути призначеною на посаду судді є позитивним, погодилися $96 \%$ опитаних суддів.

(С) Ю. Ю. Боброва, 2019 
Саме сутнісне розуміння категорії «ґендеру» лягло в основу аналізу ґендерної асиметрії в суддівській діяльності, де він проходить червоною канвою і лягає в основу досліджуваної проблематики. Диференціація за ознакою статі, яка на перший погляд не має чіткого вираження, при більш грунтовному її вивченні знаходить свій прояв чи не у всіх аспектах суспільного та державницького життя, не оминаючи при цьому і судову систему. Важливість врахування ґендеру в урегулюванні суспільних відносин поділяють $95 \%$ опитаних автором суддів, що свідчить про важливість та актуальність цього феномену на сучасному етапі розвитку нашого суспільства.

За даними опитування, судді-чоловіки мають набагато більше можливостей у професійному зростанні, аніж жінки, на що вказали $75 \%$ опитаних респондентів чоловіків, $90 \%$ - жінок, $20 \%$ чоловіків та $7 \%$ жінок цей факт заперечили; а $5 \%$ та $3 \%$ відповідно не змогли відповісти. Більше того, $64 \%$ опитаних суддів-чоловіків та $80 \%$ суддів-жінок вважають, що доступ до суддівської посади та обрання на керівну посаду чи посаду вищого рівня не є однаково рівним для чоловіків і жінок: $27 \%$ і $24 \%$ відповідно не погоджуються з цим, $9 \%$ і $6 \%$ не змогли відповісти.

Аналізуючи викладене, слід зауважити, що виникає необхідність у запровадженні гендерно-чутливої політики в судових установах з метою забезпечення прав жінки на доступ до суддівської професії та на кар'єрне зростання, реалізацію якої варто покласти на Вищу раду правосуддя, Вищу кваліфікаційну комісію суддів України. 87\% опитаних автором суддів вважають, що стиль керівництва на адміністративній посаді судді-жінки і судді-чоловіка відрізняється, $9 \%$ - заперечили вказане, $4 \%$ - не змогли відповісти на це запитання.

Аналіз досліджень ґендерних стереотипів демонструє «індиферентність» українських громадян до жінки-голови суду. Більшість із них вважає більш важливим комплекс особистісних рис та якостей керівника судової установи, ніж його приналежність до тієї чи іншої статі. Результати емпіричного дослідження показали, що $70 \%$ респондентів-суддів вважають, що голова суду жінка - це радше виняток, чим звичне явище, $24 \%$ так не думають, а $6 \%$ не надають статі керівника судової установи жодного значення.

Аналіз результатів опитування суддів, отриманих за методикою «Чи здатні ви стати керівником?», адаптованої автором до суддівської діяльності, дозволяє стверджувати, що більшість суддів володіє значною кількістю задатків стати добрим керівником із сучасним стилем поведінки. У відсотковому співвідношенні $41 \%$ отримали судді-жінки, $59 \%$ - судді-чоловіки.

На наявність різниці у постановлених рішеннях суддів-чоловіків і суддів-жінок вказало $82 \%$ опитаних суддів, $10 \%$ негативно поставилися до вказаного, $8 \%$ не змогли висловити свою думку з приводу наведеного. Беззаперечно, саме виконання сімейних і материнських обов'язків є перепоною для успішної кар'єри багатьох жінок, хоча в якості перешкоди на шляху до професійного зростання називають i відсутність у жінки такого прагнення. Таким чином, асиметрія сприйняття між чоловіками та жінками перешкод для кар'єрного зростання лежить у площині «нам не довіряють» / «вони самі не прагнуть». 
На жаль, на суспільно-стереотипному рівні батьківство - це переважно материнство. Роботодавець частіше відмовить при прийнятті на роботу жінкам, оскільки в патріархальному суспільстві основна роль жінки пов'язана, в першу чергу, із материнством. Жінки завжди $е$ «потенційними матерями», тими, які в будь-який момент можуть завагітніти і піти в декрет. Наведені гендерні установки і реальна поведінки як жінок, так і чоловіків, зокрема щодо «терпимості» до дискримінації, пояснюється сучасною низькою ґендерною культурою в суспільстві. I хоча офіційно ґендерна нерівність між чоловіком і жінкою майже зникла - безліч стереотипів досі не подолано. Підсумки дослідження показали, що у $30 \%$ судів негативно ставляться до декретної відпустки судді, у $39 \%$ випадків ставлення є нейтральним, 28\% - звичним, як і повинне бути, $3 \%$ респондентів не змогли відповісти на поставлене запитання.

Так, постійний конфлікт між професійними та родинними, материнськими обов’язками травмує та виснажує суддю-жінку, породжує у неї комплекс вини. Лише в останні роки поступово розвінчується міф про зобов'язання матері бути нерозлучною з дитиною перші роки їі життя. Неналежна збалансованість вимагає від неї створення власної стратегії розуміння з боку родини, водночас породжуючи певні стреси; брак націленості на працю та інші негативні наслідки наведеної ситуації. 50\% опитаних автором суддів-чоловіків вказали, що витрачають на потреби родини весь вільний від роботи час; $14 \%$ - половину, ще $7 \%$ - третину, а $29 \%$ взагалі не має такого часу. При чому повністю себе присвячують родині $99 \%$ суддів-жінок, лише $1 \%$ вказали на відсутність часу на сім'ю, але, як виявилося, у них немає малолітніх чи неповнолітніх дітей.

Як свідчать дані опитування, $34 \%$ суддів-батьків та $74 \%$ суддів-матерів переживають певний дискомфорт, пов'язаний зі спробою поєднати роботу та сім'ю, що свідчить про складність «встановлення балансу між обов'язками на роботі та в родині». Тому баланс у цьому питанні - це розкіш, а дотримання рівності рівноваги - необхідність. 78\% опитаних у ході емпіричного дослідження респондентів суддів-чоловіків вказали на необхідність надання суддям-жінкам, у яких маленькі діти, гнучких робочих графіків задля уникнення конфлікту між професійними та родинними, материнськими обов’язками. У респондентів цей жінок показник склав 99\%. Врахування психо-фізіологічних відмінностей суддів-чоловіків і суддів-жінок під час розподілу навантаження в суді вважають доречним $80 \%$ опитаних суддів. Відсоток, що не підтримують вказану позицію, становить 12 , не змогли відповісти на це запитання $8 \%$ опитаних.

На запитання анкети: «Чи варто враховувати гендерний аспект при визначенні спеціалізації судді з розгляду судових справ», 75\% суддів відповіли ствердно, $12 \%$ не поділяють такої думки, $13 \%$ не змогли відповісти на це запитання. Результати підтверджують позицію автора з приводу доцільності трансформації усталеного бачення механізму відправлення судочинства з урахуванням гендерного компоненту, що в кінцевому результаті призведе тільки до позитивних наслідків та підвищить якість правосуддя.

Корінним принципом професійної моралі суддів є справедливість. Без цієї моральноїякості діяльністьпо діійсненнюправосуддя втрачає свій зміст. Автором вста- 
новлено, що норми-цінності суддів-чоловіків і суддів-жінок суттєво відрізняються: перші обирають дотримання закону (52\%) і захист прав (26\%), а другі - справедливість $(70 \%)$, що підтверджується результатами цього емпіричного дослідження.

Також автором було досліджено гендерні особливості емоційного стану суддів під час судового розгляду шляхом опитування респондентів з цього приводу. Результати дозволити сформувати наступну картину. $87 \%$ суддів відчувають включення (високу зацікавленість), 62\% тривогу (внутрішне напруження, переживання) під час відправлення судочинства (серед них 68\% - це судді-жінки і лише $32 \%$ - судді-чоловіки). На пасивність та цейтнот (емоційний дискомфорт викликаний бажанням стрімко пришвидшити хід судового засідання) вказали $21 \%$ суддів, у гендерному розрізі - $42 \%$ склали жінки, $58 \%$ чоловіки. Також $11 \%$ опитаних зазначили про байдужість та злість (59\% - чоловіки, $41 \%$ - жінки), а $9 \%$ - про розгубленість та побоювання (29\% - чоловіки, $71 \%$ - жінки). Наведене підтверджує позицію автора щодо існування ґендерних особливостей особистості судді та необхідність їх врахування у його діяльності. Вони проявляються під час усього судового процесу, впливають на специфіку судового розгляду: всі пізнавальні процесу, у тому числі дослідження доказів, комунікативну діяльність (допити), організаційні моменти судового процесу та виховний його момент.

У ході анкетування суддів досліджувалися особливості комунікативного контролю суддів у гендерному розрізі, який відіграє важливу роль у безконфліктному спілкуванні. Як показали результати дослідження, судді-жінки мають низький рівень комунікативного контролю, що свідчить про те, що вони більш безпосередні і відкриті у спілкуванні, у тому числі під час судового розгляду. Суддям-чоловіками характерний високий комунікативний контроль, а це означає, що вони «рільтрують» розмову, управляють вираженням своїх емоцій.

За результатами проведеного емпіричного дослідження, значний відсоток опитаних суддів (56\%) вважають, що більшість позовів про захист від дискримінаційних дій за ознакою статі носять «надуманий характер» і свідчать про бажання позивача покарати відповідача.

Результати проведеного емпіричного дослідження свідчать, що серед професійно-правових проблем суддів для суддів-жінок (59\%) найбільш гострим є питання надмірного, непропорційного судового навантаження та пов'язаного із ним браку часу для належного вивчення справ, що надійшли на розгляд, та підготовки до їх слухання; можливості самовдосконалення та підвищення кваліфікації.

Належний рівень матеріально-технічного, організаційного забезпечення в роботі для суддів-чоловіків є питанням номер один (на це вказали $47 \%$ опитаних суддів-чоловіків), оскільки для них їх успішність, досягнення та статус вимірюється розміром власного заробітку та успіхами в професійній діяльності, величиною та ремонтом службового кабінету, найновішою моделлю комп'ютера і так далі. Таке переконання має біблійне походження з Нового Заповіту, де зазначається: «Коли хтось не дбає про себе, а надто про свою родину, тоді він відрікся віри й гірший за невірного» [1]. Подібні вказівки є в четвертому розділі Корану: «Чоловіки захищають та утримують жінок, тому що Аллах дав їм більше сили, ніж жінкам, і тому що вони підтримують їх зі своїх доходів» [2]. 
Серед найбільш актуальних професійно-правових проблем встановлено відсутність єдиної судової практики, на що вказало $23 \%$ опитаних суддів, серед яких $26 \%$ - судді-чоловіки та 74\% - судді-жінки. Ствердна відповідь на запитання цього опитування: «Чи має стать судді значення для розгляду певної категорії справ» у 76\% випадків наштовхнула автора на думку про необхідність прослідкувати зв'язок між ґендерними відмінностями суддів і винесеними ними рішеннями. Таке дослідження автор провела шляхом аналізу окремої думки суддів (як часто суддя був / була автором думки, яку не сприймали інші колеги), викладеної в Єдиному державному реєстрі судових рішень за 2012-2019 роки із кримінального, цивільного, господарського судочинства. Наведене підтверджує, що судді-жінки чіткіше формулюють свою суддівську позицію (58\% ) по відношенню до існуючих практик вирішення судових спорів, бачать їх вирішення по-іншому, аніж чоловіки $(42 \%)$.

Визначаючи стресори у суддівській діяльності, автору вдалося з'ясувати, що найбільший відсоток респондентів вказали на значне судове навантаження - 59\% ; на другому місці - постійний дефіцит часу $41 \%$, далі - тиск сторін $37 \%$ та скарги $31 \%$; практично однакова кількість опитаних вказала на високу відповідальність за прийняте рішення - $26 \%$, напруженість через вибір правильного рішення серед альтернативних - 21\% ; необхідність оперувати великим обсягом інформації - $19 \%$ та підтримувати високий рівеньпідготовки-17\% . У гендерному розрізі-чоловічі стресори: надмірне судове навантаження, вибір, відповідальність, тиск сторін; жіночі стресори: велике судове навантаження, тиск сторін, постійний дефіцит часу, скарги.

Проведений аналіз кількості постановлених суддями окремих ухвал за даними Єдиного державного реєстру судових рішень за період 2018-2019 років підтвердив гіпотезу автора про те, що судді-жінки внаслідок підвищеної емоційності критичніше ставляться до порушень закону та гостріше на них реагують, не можуть працювати «без особистого ставлення» до суддівської діяльності й своїх колег,

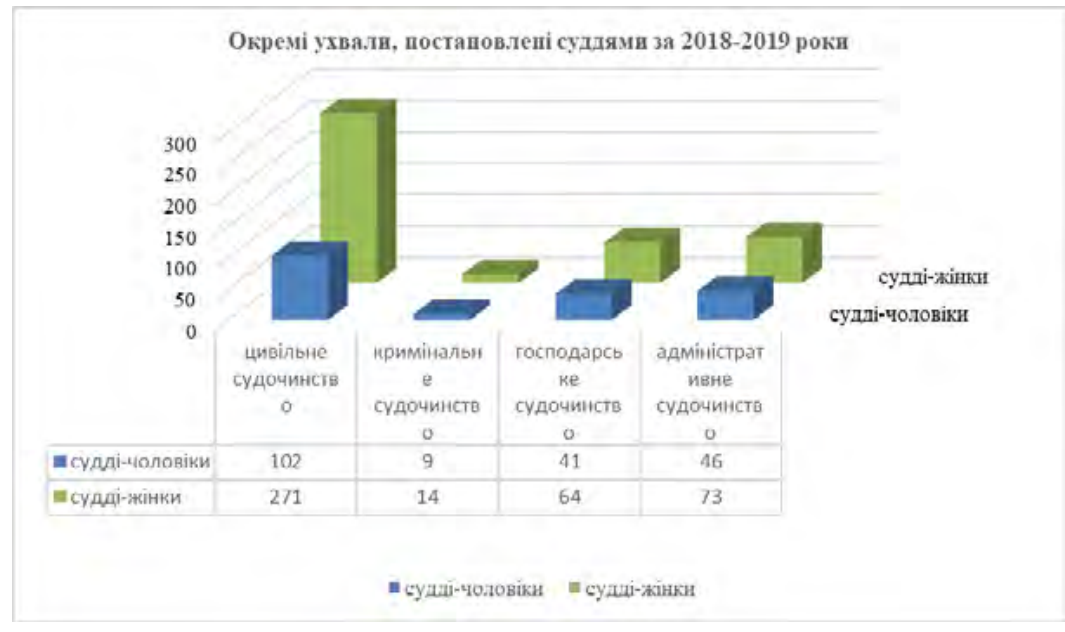

Рис. 1. Кількість окремих ухвал, постановлених суддями за 2018-2019 роки 
а судді-чоловіки частіше ігнорують емоційну напруженість процесу відправлення судочинства, що вбачається із рис. 1.

Визначаючи шляхом анкетування рівень гендерної дискримінації у судах за методикою «Визначення гендерної дискримінації», адаптованої до суддівської діяльності вдалося встановити, що жінки не однаково цінуються як чоловіки, хоча стереотипні установки щодо них змінюються на краще; відсутні програми рівних можливостей для чоловіків і жінок, не завжди має місце адекватне ставлення до декретної відпустки тощо, а тому задля досягнення ґендерного паритету потрібно запровадити ряд змін та реформ.

Визначаючи, яка з країн (Швеція, Німеччина чи Канада) досягла найбільшого успіху у реалізації гендерного паритету за результатами опитування суддів, автор встановила, що 41\% опитаних вважають, що це Швеція, 26\% - Німеччина, 15\% Канада, 18\% респондентам нічого з цього приводу не відомо. 3'ясовуючи думку опитаних суддів про необхідність використання міжнародного досвіду реалізації принципу гендерного паритету, 85\% опитаних відповіли ствердно, $4 \%$ - не погодилися з цим, $11 \%$ не змогли відповісти.

Висновки. Здійснене автором статті дослідження ґендерного аспекту суддівської діяльності дозволило виявити вплив статі як судді, так і учасника судового провадження на процес відправлення судочинства. Наведені автором числові показники можуть бути використані у практичній діяльності судових органів з метою реалізації ґендерного паритету, забезпечення гендерної рівності.

\section{Jimepamypa}

1. Перше послання св. апостола Павла до Тимофія 5:8. URL: https://www.truechristianity.info/ua/ bible/1_tim_ua.php (дата звернення: 27.11.2018).

2. Коран онлайн. URL: https://quran-online.ru/4/saadi (дата звернення: 27.11.2018).

\section{Анотація}

Боброва Ю. Ю. Окремі аспекти сутності гендеру в суддівській діяльності: до постановки проблеми. - Стаття.

Адаптація національного законодавства до міжнародних стандартів забезпечення гендерної рівності у всіх без виключення сферах суспільних відносин, у тому числі і в юридичній науці, створили підвалини гендерного підходу у наукових дослідженнях. Саме тотальне впровадження гендерної ідеології у різні сфери діяльності детермінує роль ґендерного підходу, завдяки якому можливе здійснення різнопланових досліджень із гендерної проблематики.

Для грунтовного дослідження питання ґендерного аспекту суддівської діяльності та отримання достовірних результатів необхідно гармонійно поєднати сучасні методологічні інструментарії і підходи міждисциплінарного характеру з науковими здобутками минулого. На підставі проведеного емпіричного дослідження у статті піднімається питання гендерного виміру суддівської діяльності в контексті таких питань, як ґендерна дискримінація, гендерна рівність, гендерна асиметрія за статевою ознакою. За його результатами вдалося відобразити реальну картину реалізації гендерного паритету в судовій системі в цілому, з розмежуванням залежно від судової інстанції та сформувати розуміння тих чи інших проблем суддями-чоловіками та суддями-жінками, визначити спільний знаменник для них та сфери, які не дотикаються в силу їх різного сприйняття.

Формування ґендерного підходу в правовому пізнанні - досить нова наукова парадигма, прийняття якої передбачає перегляд багатьох звичних уявлень і цінностей та утвердження нових світоглядних орієнтацій. Його змістова сутність полягає не просто у виявленні відмінностей між чоловіком і жінкою, а й у впровадженні в право нових моделей суспільних відносин, що підлягають правовому регулюванню. Вирішення проблеми викорінення гендерної асиметрії українського судочинства значною мірою залежить від комплексного використання різних методологічних підходів, принципів та методів наукового пізнання при дослідженні конкретних аспектів, адже тільки у їх органічній єдності 
можна ефективно побудувати модель забезпечення рівних прав та можливостей жінок і чоловіків-суддів. Вирішення вказаного питання потребує розроблення надійних засобів вимірювання гендерної специфіки суддівської діяльності загалом та окремих її аспектів зокрема.

Ключові слова: суд, суддя, ґендер, суддівська діяльність, емпіричне дослідження, результати.

\section{Summary}

Bobrova Yu. Yu. Some aspects of gender in judicial activity: about the problem. - Article.

The adaptation of national legislation to international standards of gender equality in all areas of social relations, including in the field of legal science, has created the foundations for a gender approach in research. It is the total implementation of gender ideology in various spheres of activity that determines the role of the gender approach, through which diverse research on gender issues is possible. For the primary supply of the gender to the aspect of judiciary activity and the decisiveness of the most reliable results, we need to harmoniously follow the methodological and instrumental methods of medical practice. On the basis of the empirical research, the article raises the issue of gender dimension of judicial activity in the context of such issues as gender discrimination, gender equality, gender asymmetry.

As a result, it has been possible to reflect the real picture of gender parity in the judiciary as a whole, with a differentiation depending on the court and to form an understanding of certain issues by male and female judges, to determine a common denominator for them and the areas not covered by them. the power of their different perceptions. The formation of the gender approach in legal knowledge is a rather new scientific paradigm, the adoption of which involves the revision of many common perceptions and values and the adoption of new worldviews. Its substantive essence lies not only in identifying differences between a man and a woman, but also in introducing into the law new models of social relations subject to legal regulation.

The solution to the problem of eradicating the gender asymmetry of the Ukrainian judiciary depends to a large extent on the complex use of different methodological approaches, principles and methods of scientific knowledge in the study of specific aspects, since only in their organic unity can a model of ensuring equal rights and opportunities of women and men of judges be effectively constructed. Addressing this issue requires the development of reliable means of measuring the gender specificity of judicial activity in general and of certain aspects of it in particular.

Key words: court, judge, gender, refereeing, empirical research, results. 